5. Калаков, Н.И. Методология прогностического исследования в глобалистике: учебное пособие для вузов / Н.И. Калаков. - М.: Академ. проект: Культура, 2015. - 746 с.

6. Лущенко, П.Р. Бизнес-модель открытых инноваций / П.Р. Лущенко // Инновационная наука. - 2017. - №8. С.76 -79.

7. Макарян, И.А. Бизнес-модель в инноватике / И.А. Макарян // Инновационная экономика. - 2018. - №8. C.47-49.

8. Официальный сайт знания Китая [Электронный ресурс]. - Режим доступа: http://www.docin.com/p154829699.html (Дата обращения: 02.11.2020).

9. Официальный сайт информации Китая [Электронный ресурс]. - Режим доступа: http://www.askci.com/freereports/2011-04/20114251930.html (Дата обращения: 02.11.2020).

10. Официальный сайт консалтинга Китая [Электронный ресурс]. - Режим доступа: http://www.hdcmr.com/bgfree43600.html (Дата обращения: 02.11.2020).

11. Петренко, М.Д. Разработка инновационной бизнес-модели государственного франчайзинга / М.Д. Петренко // Вестник ТГУ. - 2018. - №7. - С.77-79.

12. Пироверин, М.Д. Инновации бизнес-моделей / М.Д. Пироверен // Известия СПбГУ . - 2018. - №6. - С.55-59.

13. Пулий, Л.П. Модель бизнес-процессов предприятия / Л.П. Пулий // Транспортное дело. - 2019. - №6. - С. 1723.

14. Романенко, Д.Л. Представление бизнес-стратегии организации в форме бизнес-модели / Д.Л. Романенко // Международный научно-исследовательский журнал. - 2019. - №8. - С. 67-71.

\title{
Навдаева С.H. \\ Эффективность производства молока в сельскохозяйственных предприятиях Нижегородской области
}

ФГБОУ ВО Нижегородская ГСХА (Россия, Нижний Новгород)

doi: 10.18411/trnio-09-2021-24

\section{Аннотация}

В статье на материалах сельскохозяйственных предприятий Нижегородской области проанализирована эффективность производства и реализации молока, выявлены факторы ее роста.

Ключевые слова: молоко, эффективность, сбыт, сельскохозяйственное предприятие.

\section{Abstract}

The article analyzes the efficiency of milk production and sale on the materials of agricultural enterprises of the Nizhny Novgorod region, identifies the factors of its growth.

Keywords: milk, efficiency, sales, agricultural enterprise.

Введение. Молочное скотоводство - это отрасль, которая в условиях Нижегородской области является наиболее прибыльной. В большинстве сельскохозяйственных предприятий это главная отрасль, определяющая производственное направление, и от ее развития зависит рентабельность производства.

Материалы и методы исследования. Исходной информацией для исследования послужили материалы отчетности сельскохозяйственных предприятий Нижегородской области. В ходе исследования использованы экономико-статистические методы, графический метод.

Обсуждение результатов. В Нижегородской области по итогам 2020 года в хозяйствах всех категорий валовое производство молока составило - 641,8 тыс. тонн $(103,0 \%$ или +18,4 тыс. тонн к 2019 году), поголовье коров составило 106,1 тыс. голов. Сельскохозяйственными организациями и крестьянскими (фермерскими) хозяйствами по итогам 2020 года произведено 574,3 тыс. тонн молока с ростом 23,2 тыс. тонн $(104,2 \%$ к уровню 2019 года), поголовье коров 95,0 тыс. голов. Валовое производство молока увеличено в 31 районе области. Производство молока в Нижегородской области ежегодно растет, причем в расчете на 100 га сельскохозяйственных угодий ежегодный рост составляет 18,083 ц, о чем свидетельствуют данные рисунка 1. 


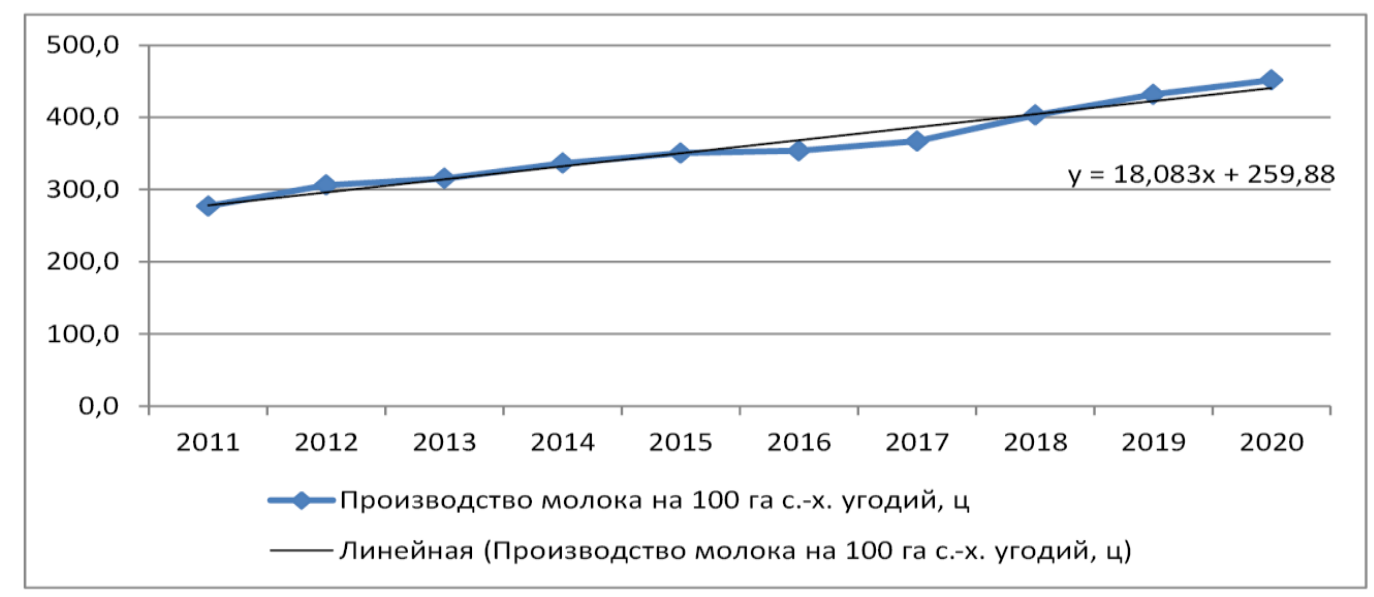

Рисунок 1. Динамика производства молока на 100 га сельскохозяйственных угодий в Нижегородской области

Предприятия, которые специализируются на производстве молока, как правило, получают высокую прибыль и финансово устойчивы. Исследованиями установлено, что в молочном скотоводстве прибыль от реализации с ростом продуктивности растет [1]. Результаты расчетов наглядно представлены на рис.2.

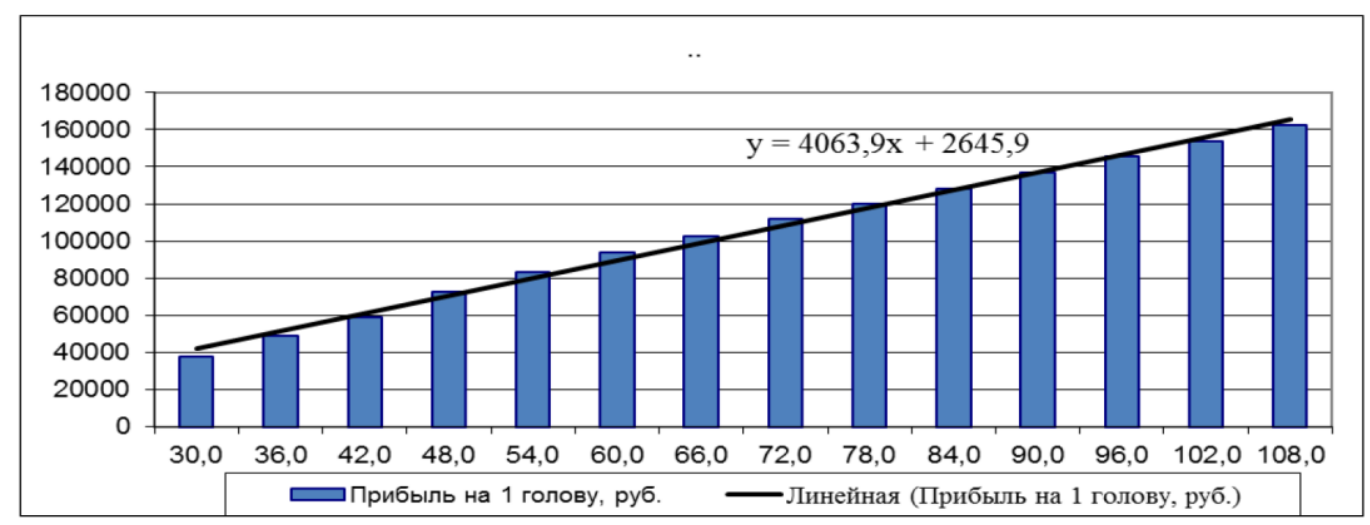

Рисунок 2. Зависимость прибыли от реализаџии молока от продуктивности коров

Рассмотрим показатели эффективности производства молока на примере одного из передовых предприятий Нижегородской области, которое специализируется на производстве молока, в структуре реализованной продукции доля выручки от реализации животноводческой продукции составляет более $90 \%$.

Основные показатели производства и реализации молока представлены в таблице 1.

Таблица 1

Показатели экономической эффективности производства и реализации молока

\begin{tabular}{|c|c|c|c|c|}
\hline Показатели & 2018 г. & 2019 г. & 2020 г. & $\begin{array}{c}2020 \text { г. к } \\
2018 \text { г.\% }\end{array}$ \\
\hline Реализовано, $и$ & 16589 & 20135 & 23426 & 141,21 \\
\hline Товарность, \% & 90,6 & 91,9 & 91,2 & 100,75 \\
\hline Выручка, тысс. руб. & 32604 & 43378 & 54490 & 167,13 \\
\hline Цена 1 и, руб. & 1965,4 & 2154,36 & 2325,06 & 118,30 \\
\hline $\begin{array}{c}\text { Полная себестоимость реализованного молока, тыс. } \\
\text { руб. }\end{array}$ & 30690 & 36203 & 42184 & 137,45 \\
\hline Полная себестоимость 1 и.молока, руб. & 1850,02 & 1798,01 & 1799,97 & 97,29 \\
\hline Прибыль отт реализации, тыс. руб. & 1914 & 7175 & 12306 & 642,95 \\
\hline Рентабельность производства, \% & 6,2 & 19,8 & 29,2 & 467,76 \\
\hline
\end{tabular}


Реализация молока за исследуемый период выросла на 41,2%, этому способствовал рост продуктивности коров. Выручка от реализации молока за исследуемый период выросла на $67,1 \%$, что обусловлено ростом цены реализации.

При этом полная себестоимость реализованного молока снизилась на $2,7 \%$. Одновременный рост цены и снижение себестоимости привели к росту прибыли. При анализе прибыли объем продаж, цена и себестоимость являются факторными показателями. Результаты факторного анализа прибыли представлены в таблице 2.

В 2020 году по сравнению с 2018 годом прибыль от реализации молока выросла на 10387 тыс. руб., в т. ч. за счет увеличения объема реализации прибыль выросла на 788,85 тыс. руб., за счет роста цены - на 8425,4 тыс. руб. и на 1172,47 тыс. руб. за счет снижения полной себестоимости.

Результаты факторного анализа прибыли от реализащии молока

\begin{tabular}{|c|c|c|c|c|c|c|c|c|c|c|}
\hline \multirow{3}{*}{$\begin{array}{c}\text { Вид } \\
\text { продук- } \\
\text { иии }\end{array}$} & \multicolumn{2}{|c|}{$\begin{array}{c}\text { Объем } \\
\text { реализачии, u }\end{array}$} & \multicolumn{2}{|c|}{$\begin{array}{c}\text { Цена } \\
\text { реализачии } 1 \text { u, } \\
\text { руб. } \\
\end{array}$} & \multicolumn{2}{|c|}{$\begin{array}{c}\text { Полная } \\
\text { себестоимость } \\
1 \text { и, руб. } \\
\end{array}$} & \multicolumn{4}{|c|}{$\begin{array}{c}\text { Отклонение прибыли (+,-) } \\
\text { тыс. руб. }\end{array}$} \\
\hline & \multirow{2}{*}{$\begin{array}{l}2018 \\
2 .\end{array}$} & \multirow{2}{*}{$\begin{array}{l}2020 \\
2 .\end{array}$} & \multirow[b]{2}{*}{$2018 z}$. & \multirow[b]{2}{*}{$2020 z}$. & \multirow[b]{2}{*}{20182.} & \multirow[b]{2}{*}{$2020 z}$. & \multirow[b]{2}{*}{ Общее } & \multicolumn{3}{|c|}{ в т.ч. за счет } \\
\hline & & & & & & & & $\begin{array}{c}\text { Объема } \\
\text { реализации }\end{array}$ & иены & $\begin{array}{c}\text { полной } \\
\text { себестоимости }\end{array}$ \\
\hline Молоко & 16589 & 23426 & 1965,4 & 2325,1 & 1850,0 & 1799,9 & 10387 & 788,8 & 8425,5 & 1172,4 \\
\hline
\end{tabular}

Молочное скотоводство - самая доходная отрасль на предприятии, прибыль от продаж составила в 2020 году 12306 тыс. руб. Прибыль от продаж в целом по предприятию составила 12187 тыс. руб., соответственно, доля молока в прибыли - 99 процентов.

Рентабельность производства молока с 6,2 \% в 2018 г. до 29,2 \% в 2020 году. Наибольшее влияние оказал рост цены и снижение полной себестоимости.

В структуре себестоимости молока наибольший удельный вес занимают затраты на корма (около 40 \%). Основным путем снижения себестоимости кормов, в т. ч. зерна, является рост урожайности [2].

Снизить себестоимость в условиях инфляции достаточно сложно, поэтому другим фактором роста экономической эффективности производства молока должно стать управление сбытом и рост цены реализации.

Таким образом, направлениями роста эффективности производства и реализации молока являются:

1. снижение себестоимости молока;

2. поддержка высокого качества производимого молока и рост цены реализации;

3. развитие переработки молока и производство молочной продукции повышенного спроса: сыров, живых йогуртов, напитков и т.д.;

4. разработка системы продвижения производимой продукции для проникновения на внутренние потребительские рынки под собственной маркой.

Решение данных задач возможно лишь на основе внедрения современных информационных систем в производство.

В России разработана система автоматизации процессов молочных производств при помощи "оцифровки" всех стадий процесса - система-ассистент для принятия решений в сфере сельского хозяйства, которая позволяет молочно-товарным фермам создать индивидуальную цифровую модель производства сырого молока и принимать управленческие решения на основе текущих данных, ретроспективного анализа, методов прогнозной и предписывающей аналитики. Экономический эффект такой оптимизации производства должен составить - прибавка производства на 10\%. Разработка призвана решить системные проблемы современных производителей молока, среди которых - 
отсутствие сводной аналитики хозяйства и единого подхода к организации процессов кормления животных. Решение российских специалистов предполагает создание цифровой модели производства с помощью облачных технологий, датчиков, весовых терминалов и мобильного приложения.

Эффективность сельскохозяйственного производства зависят и от обеспеченности трудовыми ресурсами. Особенно сильное влияние трудообеспеченность оказывает на изменение такого показателя, как производство молока на 100 га сельскохозяйственных угодий, и это закономерно, так как молочное скотоводство - отрасль трудоемкая, более нуждающаяся в трудовых ресурсах, нежели растениеводство [3].

Расчеты показывают, что производство молока на 100 га сельскохозяйственных угодий в хозяйствах с высокой обеспеченностью работниками (7 чел. на 100 га пашни) выше в 102 раза, чем в хозяйствах с уровнем трудообеспеченности 0,2 чел. на 100 га пашни. Выручка от реализации соответственно выше в 9,6 раза.

Производство молока - это наиболее стабильная отрасль в Нижегородской области, так как производство зерна варьирует в динамике, это обусловлено рядом факторов и, прежде всего, влиянием климатических условий.

Производство продукции растениеводства отличается низкой стабильностью. Коэффициент вариации урожайности пшеницы и картофеля за 2010-2019 гг. составил соответственно 23,0 и 26,9 \%. Принято считать, что если среднегодовой коэффициент вариации урожайности превышает 22-25\%, то территория региона относится к зонам неустойчивого земледелия. Следовательно, Нижегородская область является зоной неустойчивого земледелия.

Выводы. Таким образом, производство молока - это наиболее доходная отрасль в сельском хозяйстве Нижегородской области, основными возможностями для развития которой являются: достижение лидирующих позиций по соотношению затрат и качества производимого молока; субсидии на развитие молочного скотоводства, внедрение информационных технологий, повышение качества продукции, разработка системы продвижения продукции для проникновения на внутренние потребительские рынки.

$$
* * *
$$

1. Кулагина, Е Пути повышения эффективности производства молока/Е. Кулагина, С.Н. Навдаева// Современные тенденции в экономике, управлении и учете: теория и практика. Материалы Всероссийской научно-практической конференции с международным участием студентов и молодых ученых. Под редакцией А.Г. Самоделкина, А.А. Серова и С.И. Олониной. -2014. - с. 137-140

2. Бочкарев, М.В. Управление сбытом зерна в сельскохозяйственных предприятиях/ М.В. Бочкарев, С.Н. Навдаева//Влияние цифровой экономики на развитие аграрного сектора России. Материалы Всероссийской научно-практической конференции с международным участием студентов и молодых ученых. -2018. - с. 4144

3. Навдаева, С.Н. Влияние трудообеспеченности на экономическую эффективность использования земли в сельском хозяйстве / С.Н. Навдаева // Экономика сельскохозяйственных и перерабатывающих предприятий. - 2007. - № 12. - C. 58-59.

Орлова Л.В., Жамолиддинов У.А. Проблема роста социальных издержек в период пандемии

ФГБОУ ВО «Ульяновский институт гражданской авиаџии имени Главного маршала авиаџии Б.П. Бугаева» (Россия, Ульяновск)

doi: 10.18411/trnio-09-2021-25

Аннотация

В статье рассматривается проблема роста социальных издержек в период пандемии, влияние пандемии на малый и средний бизнес, социальные последствия пандемии, анализируется ситуация снижения социальных издержек и их последствия в последние годы, 